\title{
Quality of Life of Peri and Postmenopausal Women attending Outpatient Department of Obstretics and Gynecology of A Tertiary Care Hospital
}

Sunita Koirala, ${ }^{1}$ Naresh Manandhar ${ }^{2}$

${ }^{1}$ Nursing Department, Kathmandu Medical College, Sinamangal, Kathmandu, Nepal, ${ }^{2}$ Department of Community Medicine, Kathmandu Medical College, Sinamangal, Kathmandu,Nepal,

\begin{abstract}
Background: Many women experience menopausal symptoms during menopausal transition and postmenopausal years. This natural phenomenon often results in various psychological, somatic and urinary symptoms which impair the overall quality of life of women. This study aimed to access the quality of life of women during perimenopausal and early postmenopausal years attending outpatient department of OBGYN at Kathmandu Medical College Teaching Hospital.

Methods: A descriptive cross-sectional study of 240 perimenopausal women of aged 45-60 years attending gynaecological outpatient clinic was carried out between $15^{\text {th }}$ January to $13^{\text {th }}$ April 2017. Data were collected using Women Health Questionnaire, containing 37 questions by interview technique and analyzed using chi-square test to assess the association between sociodemographic information and the quality of life.

Results: The median age of onset of menopause was 50 years and $50.8 \%$ of respondents were having good quality of life. Sociodemographic variables such as age of women, marital status, educational level, last menstrual period and regular menstrual period were statistically significant with the quality of life of peri and postmenopausal women.

Conclusions: Menopausal symptoms are common but due to lack of awareness, they do not seek medical advice. Hence priority lies on generating awareness among women about menopause and menopausal symptoms and establishment of dedicated elderly clinic to help these women live a healthy and comfortable life.

Keywords: Menopause; perimenopause; quality of life; women.
\end{abstract}

\section{INTRODUCTION}

Menopause is a natural part of every woman's life, a transition from reproductive to non-reproductive stage. Natural menopause is recognized to have occurred after 12 consecutive months of amenorrhea, for which there is no other obvious pathological or physiological cause. ${ }^{1}$ Menopause normally occurs between 45-55 years. In Nepal, mean age was 47 years in one study. ${ }^{2}$ Many women experience menopausal symptoms during menopausal transition and postmenopausal years often result in various psychological, somatic and urinary symptoms which impair the overall quality of life (QOL) of women. ${ }^{3}$ Women's non-reproductive health is becoming an increasingly important public health concern in Nepal due to the aging population and lifestyles changes. ${ }^{1}$ Quality of life is the main goal of health care and a significant factor for individual health and it is used to plan and evaluate health care programs. ${ }^{4}$

\section{METHODS}

A cross-sectional study employing quantitative research method was used to obtain information on the quality of life of perimenopausal and postmenopausal women. Purposive consecutive sampling technique was used to select the sample. Women during peri and postmenopausal age 45-60 years visiting gynaecological outpatient department for different gynaecological complains between $15^{\text {th }}$ January to $13^{\text {th }}$ April 2017 at Kathmandu Medical College Teaching Hospital (KMCTH). Ethical clearance was taken from KMC-Institutional Review Committee, Kathmandu Medical College, Sinamangal. Respondents willing to participate in the study were selected and written consent was obtained from all study participants. Women with cardiovascular diseases, mental disorders, diseases of the kidney and liver, non-residents of Nepal, and those confined to bed because of ill-health were excluded from the study.

Sample size was calculated taking $50 \%$ of prevalence

Correspondence: Ms Sunita Koirala, Kathmandu Medical College Teaching Hospital, Sinamangal, Kathmandu, Nepal. Email: suni327070@gmail.com, Phone: +9779841327070 . 
with $95 \%$ confidence interval using formula sample size $(n)=Z^{2} p q / d^{2}$, resulting to an estimated sample size of 235 , however, during the study 240 participants were enrolled. The Women's Health Questionnaire (WHQ), ${ }^{5}$ which was designed to assess symptom perceptions during menopause transition, and for post-menopausal women was used after translating in Nepali language. Pretest was done with $10 \%$ of sample in similar setting of final data collection. Nepali version of WHQ was finalized after feedback from pretest and consulting with professional.This is a disease or population-specific instrument developed by Myra Hunter which contains 37 items in 9 dimensions. ${ }^{6}$ Other part of the questionnaire includes questions concerning the women's sociodemographic data and women's basic gynaecological history.

Data were entered into Epi Data version 3.1 then cleaned and analyzed using SPSS version16.0. The data was analyzed by using frequencies, percentage, measurement of central tendency, standard deviation and chi-square test. Among the 37 items, 6 items were reversed. All item scores were transformed into a dichotomous scale. According to the scaling and scoring of WHQ provided $0=$ Good QOL and 1= Bad QOL. Questionnaire is four point Likert scale where, if the response is Yes, definitely' or 'Yes, sometimes', then the score is 1 . If the response is 'No, not much' or 'No, not at all', then the score is 0 . The values of dependent variables were dichotomized according to the median value. For each nine scales of WHQ, women showing values over the median value was considered Bad QOL and values under the median value was considered Good QOL. ${ }^{6}$

\section{RESULTS}

A total of 240 women aged 45-60 years visiting Gynaecological outpatient department were interviewed about their age, education level, occupation, income, marital status, menopausal status and their experience of symptoms listed in the WHQ.

Among the total respondents (37.9\%) were from age group $45-50$ years and $37.5 \%$ were from $55-60$ years. Median age of respondents was 50 years. The majority of respondents $(78.3 \%)$ were from Hindu religion. Almost one-third $(31.3 \%)$ of the respondents have completed secondary level education and few (8.3\%) have bachelor and above degree.

Regarding occupation majority of respondents (60\%) were housemaker. The respondents having total family income between NPR.40,000-50,000 per month was $46.3 \%$.Very few respondents $(1.3 \%)$ were single and widow/divorced (3.3\%). Among 154 menopausal women who had menopause $51.7 \%$ respondents had menopause at the age of 50 years or below. Among 86 menstruating women $84.9 \%$ do not have regular menstrual period (Table1).

\section{Table1. Respondents' socio-demographic \\ characteristics.}

Variables Number Percent $n=240$

\begin{tabular}{|lrr|}
\hline $\begin{array}{l}\text { Age group in years } \\
\leq 50\end{array}$ & 91 & 37.9 \\
\hline $51-55$ & 59 & 24.6 \\
$\geq 56 \quad$ & 90 & 37.5 \\
\hline$\quad$ Mean age=53.27, S.D $=4.48$ & & \\
\hline Religion & & \\
\hline Hindu & 188 & 78.3 \\
\hline Buddhist & 37 & 15.4 \\
\hline Christian & 11 & 4.6 \\
\hline Islam & 4 & 1.7 \\
\hline
\end{tabular}

\section{Education level}

General literate

$\begin{array}{ll}22 & 9.2\end{array}$

Primary education

57

23.8

\begin{tabular}{crr} 
Secondary education & 75 & 31.3 \\
\hline Higher secondary education & 66 & 21.5 \\
\hline Bachelor and above & 20 & 8.3
\end{tabular}

\section{Occupation}

Agriculture

$48 \quad 20$

Business $\quad 25 \quad 10.4$

\begin{tabular}{|rrr}
\hline Service & 16 & 6.7 \\
\hline Housemaker & 144 & 60 \\
\hline Others & 7 & 2.9
\end{tabular}

Family Income per Month (NPR)

$\begin{array}{crr}20000-29999 & 14 & 5.8 \\ 30000-39999 & 30 & 12.5 \\ 40000-49999 & 111 & 46.3 \\ \geq 50000 & 85 & 35.4\end{array}$

Mean income $=41000 ; S . D=8400$

\section{Marital status}

\begin{tabular}{lrr} 
Marital status & & \\
\hline \multicolumn{1}{l}{ Single } & 3 & 1.3 \\
\hline Double & 229 & 95.4 \\
\hline Widow/Divorce & 8 & 3.3 \\
\hline Last menstrual period & & \\
\hline <1year & 86 & 35.8 \\
\hline 1year & 154 & 64.2 \\
\hline
\end{tabular}




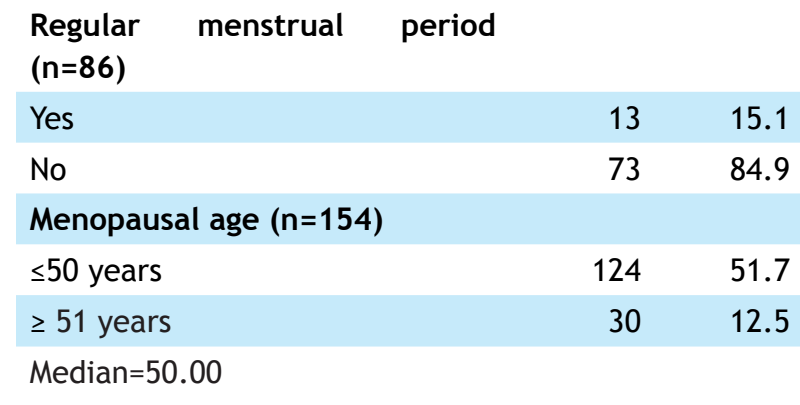

Quality of life regarding each items in 9 dimensions shows that depressed mood and somatic symptoms both contains 7 items where Good QOL is seen in 3 items each. All items in Sexual behaviour, sleep problems and attractiveness had Bad QOL (Table 2).

\begin{tabular}{lrrr}
$\begin{array}{l}\text { Table 2. Total number of items } \\
\text { quality of life. }\end{array}$ & $\begin{array}{r}\text { No. } \\
\text { of } \\
\text { Items }\end{array}$ & $\begin{array}{r}\text { Items } \\
\text { with Good } \\
\text { QOL }\end{array}$ & $\begin{array}{r}\text { Items } \\
\text { with Bad } \\
\text { QOL }\end{array}$ \\
\hline Depressed mood & 7 & 3 & 4 \\
\hline Somatic symptoms & 7 & 3 & 4 \\
\hline Memory/Concentration & 3 & 2 & 1 \\
\hline Vasomotor symptoms & 2 & 1 & 1 \\
\hline Anxiety/ Fears & 4 & 2 & 2 \\
\hline Sexual behaviour & 3 & 0 & 3 \\
\hline Sleep problems & 3 & 0 & 3 \\
\hline Menstrual symptoms & 4 & 3 & 1 \\
\hline Attractiveness & 2 & 0 & 2 \\
\hline
\end{tabular}

Among total respondents almost half $(50.8 \%)$ of the respondents are having good quality of life and $49.2 \%$ are having bad quality of life. Out of which $35.8 \%$ respondents were perimenopausal women having $58.2 \%$ good QOL and 64.2\% respondents were menopausal women having $46.7 \%$ good QOL(Table 3 ).

\begin{tabular}{|c|c|c|c|}
\hline $\begin{array}{l}\text { Menopausal } \\
\text { Status }\end{array}$ & $\begin{array}{r}\text { Good QOL } \\
\qquad(n) \%\end{array}$ & $\begin{array}{r}\text { Bad QOL } \\
\text { (n)\% }\end{array}$ & $\begin{array}{l}\text { Total } \\
\text { (n)\% }\end{array}$ \\
\hline Perimenopausal & $(50) 58.2$ & (36) 41.8 & (86)35.8 \\
\hline Menopausal & (72)46.7 & $(82) 53.3$ & $(154) 64.2$ \\
\hline Total & (122)50.8 & (118)49.2 & $(240) 100$ \\
\hline
\end{tabular}

Age of women, marital status, educational level and menstrual regularity are statistically significant with quality of life of peri and postmenopaual women (Table 4).
Table 4. Association between demographic variables and quality of life.

\begin{tabular}{cllll} 
Variables & Good QOL & Bad QOL & $x^{2}$ value & $\begin{array}{l}\mathrm{p} \\
\text { value }\end{array}$ \\
& $\mathrm{n}(\%)$ & $\mathrm{n}(\%)$ & & \\
\hline \multicolumn{5}{c}{ Age in Years } \\
$\leq 50$ & $51(41.8)$ & $40(33.9)$ & & \\
$51-55$ & $34(27.9)$ & $25(21.2)$ & 5.482 & $0.045^{*}$ \\
$\geq 56$ & $37(30.3)$ & $53(44.9)$ & &
\end{tabular}

\section{Marital status}

$\begin{array}{ccccc}\begin{array}{c}\text { Single/ } \\ \text { widow/ } \\ \text { divorce }\end{array} & 2(18.2) & 9(81.8) & & \\ \text { Double } & 120(52.4) & 109(47.6) & & \\ \text { Dound } & & & \end{array}$

\section{Educational level}

\begin{tabular}{|c|c|c|c|c|}
\hline $\begin{array}{l}\leq \text { Secondary } \\
\text { education }\end{array}$ & $73(59.8)$ & $81(68.6)$ & \multirow[b]{2}{*}{2.863} & \multirow[b]{2}{*}{0.009} \\
\hline $\begin{array}{l}\geq \text { Higher } \\
\text { secondary } \\
\text { education }\end{array}$ & $49(40.2)$ & $39(31.4)$ & & \\
\hline \multicolumn{5}{|c|}{ Regular menstrual period $(n=86)$} \\
\hline Yes & $11(84.6)$ & $2(15.4)$ & & \\
\hline No & $39(53.4)$ & $34(46.6)$ & 4.411 & $0.032^{*}$ \\
\hline
\end{tabular}

\section{*Significance at $5 \%$}

\section{DISCUSSION}

Globally, the natural age at menopause is 45 to 55 years. ${ }^{1}$ In this study, median age of menopause was 50 years and were mainly secondary level literates with a usual occupation as housemaker. This result is consistent with studies conducted within Nepal that found age ranges of $45-50$ years. ${ }^{2,7-9}$

In this study, 50.8\% women had Good QOL. Mostly observed perimenopausal symptoms were poor sleep and memory, palpitations, restlessness, headache, hot flushes, dry vagina and loss of interest in sexual activity. This finding is consistent with the studies done to observe menopausal health status at Kapilvastu district of Nepal, study done at rural terai of Nepal and study done at Guwahati, India shows as common symptoms. Similarly, study done to observe symptoms among perimenopausal and postmenopausal women shows symptoms of physical, psychological and sexual problems like palpitation, sleep disturbance, depressed mood, loss of libido and dry vagina. ${ }^{8-11}$

Age of women shows statistically significant with $\mathrm{QOL}(\mathrm{p}=0.045)$ which states that less the age of women, better the quality of life. Single/widow or divorced women had bad QOL in comparison to women living with 
their husbands $(p=0.026)$. This result is consistent with the study done at Guwahati, India ${ }^{11}$ and contrast with the study done to find out quality of life of perimenopausal and postmenopausal Polish women. ${ }^{12}$.

Regarding educational level, women having below secondary education are bearing bad QOL with comparison to women who had higher secondary education and above $(p=0.009)$. Several studies concluded that those women who had more than high school education experienced less disturbing and fewer symptoms during menopause. ${ }^{12-14}$ One study had reported that educational level had significant effect on all QOL domains. ${ }^{15}$

Among the total respondents only $86(35.83 \%)$ women were menstruating of which $15.1 \%$ women reported that they had regular periods and statistically significant with $\mathrm{QOL}(\mathrm{p}=0.032)$. This indicates that women with regular period had good QOL while the finding is contrast in a study done in Polish women shows that there is no statistical difference in the menstrual symptom of the WHQ. ${ }^{12}$

\section{CONCLUSIONS}

The prevalence of menopausal symptoms is high but due to lack of awareness, majority of the women do not seek advice for these symptoms.

\section{ACKNOWLEDGEMENTS}

Researcher would like to thank Mapi Research Trust for providing Women Health Questionnaire, Mr Sebantak Pokharel for helping in translation of questionnaire and every respondents for providing their valuable information.

\section{REFERENCES}

1. Research on the menopause in the 1990s [WHO Technical Report Series 866]Geneva: World Health Organization, 1996. PMID: 8942292.

2. Rajbhandari S, Amatya A, Giri K. Relation of Ethnicity and Menopausal Symptoms in Nepal. Journal of the South Asian Federation of Menopause Societies. 2013;1(2).50-5. [Full Text]

3. Nisar N, Sohoo NA. Severity of Menopausal symptoms and the quality of life at different status of Menopause: a community based survey from rural Sindh, Pakistan. Int J Collab Res Intern Med Public Health. 2010;2(5):118-30. [Full Text]

4. Yekke Fallah L.The Effect of physical exercise on the pulmonary function and quality of life in asthmatic patients.Int J Prev Med. 2013; 4(Suppl 1): S126-S132.

5. Hunter M. The Women's Health Questionnaire (WHQ): The development, standardization and application of a measure of mid- aged women's emotional and physical health. Qual Life Res. 2000; 9: 733-8.[Full Text]

6. Hunter M. Scaling and Scoring of the Women's Health Questionnaire (WHQ) MAPI Research Institute Lyon France. May 2002

7. Acharya D, Gautam S, Neupane N, Kaphle HP, Singh JK. Health Problems of Women Above Forty Years of Age in Rupandehi District of Nepal. Int J Health Sci Res. 2013;3(3):29-36.[Full Text]

8. Ghimire N, Dhakal P, Norrish D, Dangal G, Sharma D, Dhimal M, et al. Menopausal Health Status of Women of Kapilvastu District of Nepal. J Nepal Health Res Counc. 2015;13(31):182-7. [JNHRC]

9. Marahatta R. Study of menopausal symptoms among peri and postmenopausal women attending NMCTH. Nepal Med Coll J. 2012; 14(3): 251-255.[Full Text]

10. Paudel IS, Bhattarai S,Adhikari P, Gautam R. Gynaecological and other health problems in postmenopausal women in rural Terai. Health Renaissance. 2014;12(2): 87-91. Available from:[DOI]

11. Alakananda, Das N, Das BP. Age of Menopause and Menopausal Symptoms among women attending Gauhati Medical College and Hospital, Guwahati, Assam: A crosssectional study. Sch J App Med Sci., 2015; 3(7C):26212629. [Full Text]

12. Zołnierczuk-Kieliszek D, Kulik TB, Jarosz MJ, Stefanowicz A, Pacian A, Pacian J, et al. Quality of life in peri- and post-menopausal Polish women living in Lublin Province - differences between urban and rural dwellers. Ann Agric Environ Med. 2012;19(1):129-33.[PubMed]

13. Ozkan S, Alatas ES, Zencir M. Women's quality of life in the premenopausal and postmenopausal periods. Qual Life Res. 2005;14(8):1795-801.[PubMed]

14. Brzyski RG, Medrano MA, Hyatt-Santos JM, Ross JS.Quality of life in low-income menopausal women attending primary care clinics. Fertil Steril. 2001;76(1):4450.[PubMed]

15. Williams RE, Levine KB, Kalilani L, Lewis J, Clark RV. Menopause-specific questionnaire assessment in US population-based study shows negative impact on healthrelated quality of life. Maturitas. 2009;62(2):153-9. [PubMed] 